\title{
Characteristics of mangrove swamps managed for mosquito control in eastern Florida, USA
}

\author{
Beth Middleton $^{1, *}$, Donna Devlin ${ }^{2}$, Edward Proffitt ${ }^{2}$, Karen McKee ${ }^{1}$, Kari Foster Cretini ${ }^{1}$ \\ ${ }^{1}$ United States Geological Survey, National Wetlands Research Center, 700 Cajundome Boulevard, Lafayette, \\ Louisiana 70506, USA \\ ${ }^{2}$ Florida Atlantic University, Harbor Branch Oceanographic Institution, Fort Pierce, Florida 34946, USA
}

\begin{abstract}
Manipulations of the vegetation and hydrology of wetlands for mosquito control are common worldwide, but these modifications may affect vital ecosystem processes. To control mosquitoes in mangrove swamps in eastern Florida, managers have used rotational impoundment management (RIM) as an alternative to the worldwide practice of mosquito ditching. Levees surround RIM swamps, and water is pumped into the impoundment during the summer, a season when natural swamps have low water levels. In the New World, these mosquito-managed swamps resemble the mixed basin type of mangrove swamp (based on PCA analysis). An assessment was made of RIM, natural (control), and breached-RIM (restored) swamps in eastern Florida to compare their structural complexities, soil development, and resistance to invasion. Regarding structural complexity, dominant species composition differed between these swamps; the red mangrove Rhizophora mangle occurred at a higher relative density in RIM and breached-RIM swamps, and the black mangrove Avicennia germinans had a higher relative density in natural swamps. Tree density and canopy cover were higher and tree height lower in RIM swamps than in natural and breached-RIM swamps. Soil organic matter in RIM swamps was twice that in natural or breached-RIM swamps. RIM swamps had a lower resistance to invasion by the Brazilian pepper tree Schinus terebinthifolius, which is likely attributable to the lower porewater salinity in RIM swamps. These characteristics may reflect differences in important ecosystem processes (primary production, trophic structure, nutrient cycling, decomposition). Comparative assessments of managed wetlands are vital for land managers, so that they can make informed decisions compatible with conservation objectives.
\end{abstract}

KEY WORDS: Avicennia germinans - Crab burrowing · Functional assessment • Production · Rhizophora mangle $\cdot$ Schinus terebinthifolius $\cdot$ Soil organic matter $\cdot$ Wetland restoration

\section{INTRODUCTION}

Public demand for environmental manipulation to reduce mosquito populations is growing worldwide, particularly because of the role of mosquitoes as disease vectors (Collins \& Resh 1989, Kadlec et al. 2000, Knight et al. 2003, Patterson 2004). Manipulations of wetlands for mosquito control are common and involve either the impoundment or the dewatering of the wetland (World Health Organization 1982). These manipulations alter vegetation and hydrology and may alter vital ecosystem processes of coastal wetlands. Therefore, an assessment of the characteristics of mangrove swamps managed for mosquito control in comparison to natural swamps is relevant to the larger question of worldwide biodiversity conservation.

Assessments of the characteristics of wetlands manipulated for mosquito control are especially important along the coast of eastern Florida, where $16 \%$ of the estuarine marshes have been impounded for mosquito control (Montague \& Zale 1989), including 16200 ha of mangrove swamp (Rey \& Kain 1990). These impoundments cause 3 major changes in the physical characteristics of wetlands, including increased water levels, decreased salinity levels, and altered water exchange dynamics between the impounded site and the estuary (Montague \& Zale 1989). The first mosquito impoundments permanently flooded swamps to control mosqui- 
toes, but the flooding damaged trees over time. Eventually, many managers began to use a mosquito control strategy called rotational impoundment management (RIM), which is considered less damaging to mangrove trees (Rey \& Kain 1990). RIM involves water management in mangrove swamps using elevated summer flooding maintained by levees and water pumping. Winter water levels in RIM swamps are more similar to those of natural swamps (J. David \& D. Carlson pers. comm.).

The quality of restored wetlands can be examined by using rapid assessment techniques to compare degree of similarity in the characteristics of natural (control) versus restored wetlands, and this technique may be used to evaluate wetlands manipulated for mosquito control. The characteristics measured in these assessments often only indirectly reflect the nature of underlying ecosystem processes, because field measurements include only simple descriptions of stand structure, species richness, invertebrate composition, soil organic matter, and/or hydrological dynamics (Brinson \& Rheinhardt 1996, Simenstad \& Thom 1996, Craft et al. 1999, Field 1999, Ellison 2000). These assessments compare field characteristics in natural versus restored systems, but are at best imprecise measures of the recovery status of major ecosystem processes such as production, decomposition, nutrient cycling, and trophic dynamics.

Generally, restored wetlands are slow to develop characteristics similar to those of natural wetlands; e.g. after $15 \mathrm{yr}$, restored salt marshes do not have soil and benthic structures similar to those of natural salt marshes (Craft et al. 1999). These differences in soil and invertebrate characteristics may underlie dissimilarities in major processes related to nutrient cycling and trophic structure, so that these simpler comparisons of characteristics may provide important insight into disparities between recovering and natural ecosystems. Similarly, the recovery of most biogeochemical processes in restored mangrove systems is slow, but a few processes became similar to control swamps as early as 6 yr after restoration (McKee \& Faulkner 2000). Although a number of studies have compared restored wetlands to natural wetlands, few have compared the characteristics of RIM and breached-RIM swamps to natural (control) swamps.

In the present study, we compare the characteristics of mangrove systems managed for mosquito control including various structural, compositional, and environmental attributes of (1) RIM managed swamps, (2) breached-RIM (restored RIM managed swamps with levee breaks and no water pumping), and (3) control swamps (natural mangrove swamps with no water management for mosquito control), herein referred to as the 3 management types.
The objective of this project was to compare the characteristics of these 3 management types to determine whether structural and species composition characteristics might suggest underlying differences in ecosystem processes among the swamps. In addition to surveying the structure and composition of these mangrove swamps, we examined variation in environmental variables such as soil organic matter, age or time since last disturbance (hurricane, site creation, freezing), pore water salinity, density of crab holes, openness of canopy, and litter cover.

The following questions addressed 5 main attributes of mangrove systems including structural complexity, resistance to invasion, soil development, and support for biota:

(1) What types of natural mangrove swamps do RIM swamps most closely resemble?

(2) Do RIM and breached-RIM swamps have patterns of structural complexity and/or species richness that are similar to control swamps?

(3) Are RIM and breached-RIM swamps more subject to invasion by non-native species or herbaceous species than control swamps?

(4) Do RIM and breached-RIM swamps have less well-developed soils in terms of organic matter content than control swamps?

(5) Do RIM and breached-RIM swamps support invertebrate species important for soil aeration and development in the same way as control swamps?

\section{MATERIALS AND METHODS}

Study areas. Control swamps on natural islands and mainland spits: The study area encompassed the coastal zone of Indian River and St. Lucie Counties, Florida, including natural islands in the Pelican Island National Wildlife Refuge under the jurisdiction of the Indian River Mosquito Control District. The mangrove swamps of eastern Florida were originally forests dominated by $R$ hizophora mangle, Laguncularia racemosa, and Avicennia germinans (red mangrove, white mangrove and black mangrove, respectively), but over time the majority of these swamps have been developed for agricultural, urban and mosquito control purposes (Sime 2005).

The control swamps in the present study are the best representations of basin mangrove swamp remaining in the region. The natural mainland spits of mangrove swamp form peninsulas that jut into the Indian River Lagoon, but these were not noted before 1850 (age $>150 \mathrm{yr}$ ), according to surveyors' notes from the region. Therefore, these natural mangrove spits may have emerged due to the stabilization of the coastline caused by reengineering activities (D. Carlson pers. comm.). Sites on 3 natural islands (Indian River 
Fig. 1. Location of study sites in St. Lucie and Indian River Counties, Florida. Imp: impoundment, RIM: rotational impoundment management, Breach: Breach-RIM, H BOI: Harbor Branch Oceanographic Institution, and NWR: national wildlife refuge. Management types are depicted as: control (7 sites); RIM (8 sites), and Breached-RIM (4 sites). Also depicted are Indrio Blueway, which was a newly created RIM, and Moorings North, which was permanently impounded. Map redrawn from Google Earth (2008, available at: www.earth.google.com/intl/ en/userguide/v4/)

County: Roosevelt, Preachers and Barker Islands) and 4 mainland spits (Indian River County: spits near the Environmental Learning Center and Oslo Boat Ramp [north]; St. Lucie County: spits near Impoundment 19A and Impoundment 1 on Hook Point) were selected for this study as controls ( $\mathrm{n}=7$, Fig. 1). These natural swamps have never been impounded for mosquito control and have unmanaged hydrology and vegetation. For each study site, 'age' or the time since the last disturbance was determined as the time since the last freeze, the time since the last hurricane, or the time since creation of the site. These times were verified using aerial image examination and interviews with site managers (J. David \& D. Carlson pers. comm.).

Rotational impoundment management (RIM): Many of the coastal mangrove swamps in Indian River and St. Lucie Counties have been managed using RIM. To create a RIM swamp for mosquito control, a levee is constructed around the perimeter and water is actively pumped into the impoundment during the summer season to manage water levels. The RIM swamps are typically not excavated, although the entire impoundment site is cleared of trees at the time of construction. Culverts maintain maximum water levels of approximately
$50 \mathrm{~cm}$ in a RIM swamp; however, water levels are lower in the winter than in the summer (Fig. 2). In contrast, natural swamps in eastern Florida typically have a hydrological regime characterized by higher water levels in late summer and low water levels or dry conditions during the rest of the year (Fig. 2). In this study, 8 RIM impoundments were studied (Fig. 1). During the field work (April 2006), an additional RIM impoundment nearing completion was observed (Indrio Blueway). Originally, the Harbor Branch Oceanographic Institution sites (HBOI; Rhizophora and Avicennia 14A and 14B; Fig. 1) were isolated freshwater systems (J. David pers. comm.). For all of the management types (RIM, breached-RIM, and permanent impoundment), the date of impoundment creation was determined through interviews (J. David \& D. Carlson pers. comm.).

Breached-RIM (restored) swamps: Four former RIM swamps were breached to restore seasonal flooding. The sites were no longer pumped (S. Knights pers. comm.), the dikes had been breached (site Moorings $\mathrm{S})$, or the culverts had been opened (Impoundment \#19A, Impoundment \#24; Fig. 1).

Permanent impoundment: One study site was permanently impounded, with water pumped all year (site 


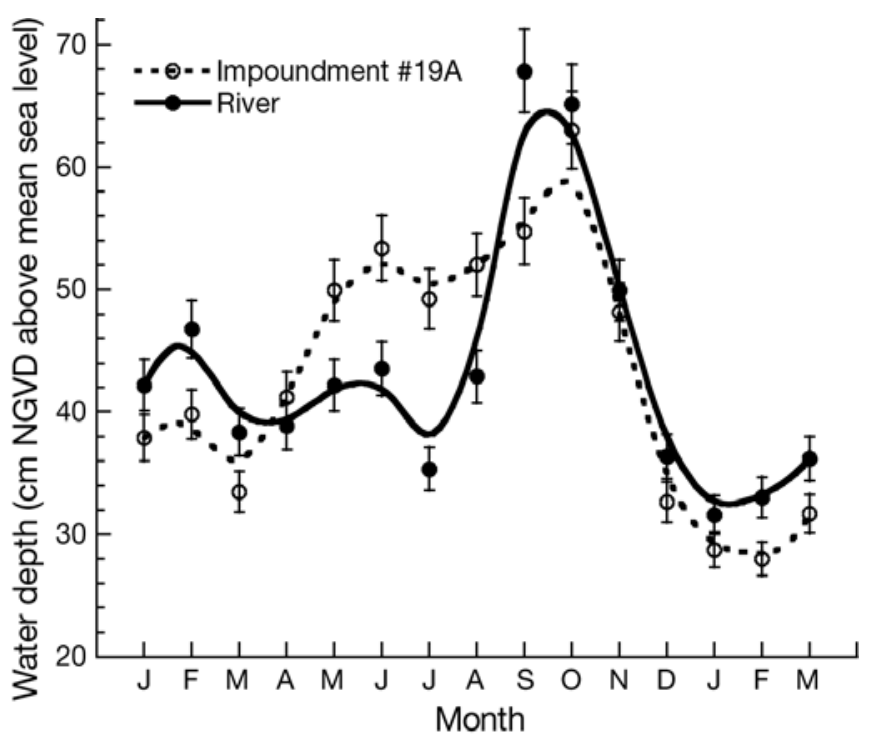

Fig. 2. Monthly mean $( \pm \mathrm{SE})$ hydrographs (cm NGVD [North American Vertical Datum] above mean sea level) from January 2005 to March 2006 for a RIM (rotational impoundment management) managed swamp (Impoundment \#19A), and adjacent river. Data for swamps with natural and with breached hydrology were not available for these sites. Data are courtesy of St. Lucie Mosquito Control District (L. Goldsmith pers. comm.)

Moorings $N_{i}$ Fig. 1). As we observed from the edge of this site, this impoundment did not have any living mangrove trees.

Sampling design. The sampling design at each site consisted of a $50 \mathrm{~m}$ linear transect with 2 plots placed at random positions starting near the point of access to the site (dock, boardwalk, or other access point). The transect was positioned parallel to the shoreline so that both plots along the transect had similar elevations. Each of the 2 sample plots ( $1 \mathrm{~m}^{2}$ each) was sampled for soil, ground vegetation, and invertebrates (no. of crab holes) as described below, so that these plots were used to estimate within-site variability. Replication was at the site level for control, RIM and breached-RIM swamps (7, 9, and 4 replicates, respectively). Field work was conducted in March 2006.

Environmental measurements. A sipper device extracted pore water at $15 \mathrm{~cm}$ depth and the pore water was stored in vials. The salinity of the pore water was measured using a refractometer. In each plot, a soil core $(2 \mathrm{~cm}$ wide $\times 15 \mathrm{~cm}$ deep) was extracted using a piston-corer. Samples were dried $\left(70^{\circ} \mathrm{C}\right)$, and analyzed for ash and organic content using a standard loss on ignition method, with $5 \mathrm{~g}$ samples heated to $400^{\circ} \mathrm{C}$ for $8 \mathrm{~h}$ (Heiri et al. 2001).

The dominance of each mangrove species was estimated visually. The height of the tallest tree within $10 \mathrm{~m}$ of the sample plot was measured by using a range finder or stadia rod (i.e. 2 trees were measured per site). Along each transect, the number of individuals of each of the tree species intercepting the line was recorded (1 transect per site), and flowers or propagules were noted. In each ground sample plot (2 per site), number of propagules per species and leaf litter cover were recorded within a $1 \mathrm{~m}^{2}$ quadrat. Leaf litter cover was categorized as: no litter, a few, some, or many leaves, almost completely covered, and covered with leaves $(0,1,25,50,75,100 \%$, respectively). In each $1 \mathrm{~m}^{2}$ plot, the number of crab holes was counted.

Percent canopy openness was estimated by using a digital camera with a hemispherical lens, with the camera positioned over each of the 2 sample points (plots). Percent canopy openness over each plot was determined from the digital photographs using Gap Light Analyzer version 2.0 software (Frazer et al. 1997, 1999, Ramsey \& Jensen 1995).

Calculations and statistical analysis. Structural and environmental parameters of mangrove swamps were analyzed using general linear model (GLM) analysis, with continuous variables fitted as traditional linear models and count variables fitted as Poisson regressions (loglinear models; JMP SAS 2007). Data collected in $1 \mathrm{~m}^{2}$ plots were analyzed with management type as the main effect and site nested within management type for the variables soil organic matter, pore water salinity, crab hole density, tree height, and canopy openness. Differences in the variance for mean tree height per site were likewise tested using loglinear variance models in GLM. One degree of freedom contrasts were based on pairwise comparisons of means of interest. Regression analysis was performed on mean salinity versus percent soil organic matter, mean salinity versus tree height, and age of swamp versus tree height (JMP SAS 2007).

The leaf area index (LAI) is an adjusted value of canopy openness based on the asymptotic equations, and is calculated as $\ln$ (percent canopy openness), which is the reciprocal of percent canopy cover (Ramsey \& Jensen 1996).

Variables expressed as percentages including canopy openness and soil organic matter were arcsine square root transformed to meet model assumptions

Table 1. Matched pair analysis of intrasite variability based on subplots for 7 variables of mangrove swamps under various management types. ${ }^{*} p<0.05$

\begin{tabular}{|c|c|c|c|}
\hline Variable & Mean difference & $t$-ratio & $\mathrm{p}$ \\
\hline Tree height (m) & 0.05017 & 0.8267 & 0.7904 \\
\hline Canopy openness (\%) & -0.02260 & -1.0862 & 0.1463 \\
\hline No. of propagules $\mathrm{m}^{-2}$ & -0.18380 & -1.7192 & $0.0514^{*}$ \\
\hline Salinity (ppt) & -0.00009 & -0.1647 & 0.4357 \\
\hline Soil organic matter (\%) & 0.02187 & 0.3710 & 0.6425 \\
\hline Litter cover $(\%)$ & -0.04130 & -0.8250 & 0.2101 \\
\hline Crab holes $\mathrm{m}^{-2}$ & -0.05600 & -0.3593 & 0.3618 \\
\hline
\end{tabular}


(Sokal \& Rohlf 1995). Multiple comparisons were made using contrasts of interest (JMP SAS 2007), where the Bonferroni adjustments of significance levels were: $p=$ 0.05/k for the total number of comparisons $\mathrm{k}=3$ or 4 , so that $\mathrm{p}=0.0167$ and 0.0125 , respectively (Sokal \& Rohlf 1995).

To examine intra-site variability, we conducted a Matched Pairs analysis (JMP SAS 2007). Of the 7 variables tested, we found a difference between pairs of plots within sites only for the number of propagules (Table 1).

To compare the characteristics of management types in this study (control, breached-RIM, and RIM), Principal Component Analysis (PCA) was performed with Varimax factor rotations on 2 axes. An ordination graph was generated (JMP SAS 2007) using site characteristics including organic matter, salinity, tree height, number of crab holes, leaf cover, LAI, as well as relative densities of Rhizophora mangle, Avicennia germinans, Laguncularia racemosa, and Schinus terebinthifolius. The relative density of each tree species was calculated as the total number of individuals per species divided by the total number of individuals for all species (Brower et al. 1997). To examine the similarity of RIM and breached-RIM to other mangrove types of the New World (e.g. mixed basin, riverine, scrub mangrove), a second PCA was performed using a procedure similar to that used to create the first ordination graph. Site characteristics were determined based on published literature sources, including salinity, tree height and relative densities of Rhizophora mangle, Avicennia germinans, Laguncularia racemosa.

\section{RESULTS}

\section{Comparison among swamp types}

RIM swamps had overlapping characteristics based on literature information on mixed basin, fringe and scrub mangrove types, but no overlap with the riverine mangrove types based on PCA of characteristics including salinity, tree height and mangrove species density (Table 2, Fig. 3). RIM swamps had lower salinities and relative densities of $\mathrm{Avi}$ cennia germinans than many other swamp

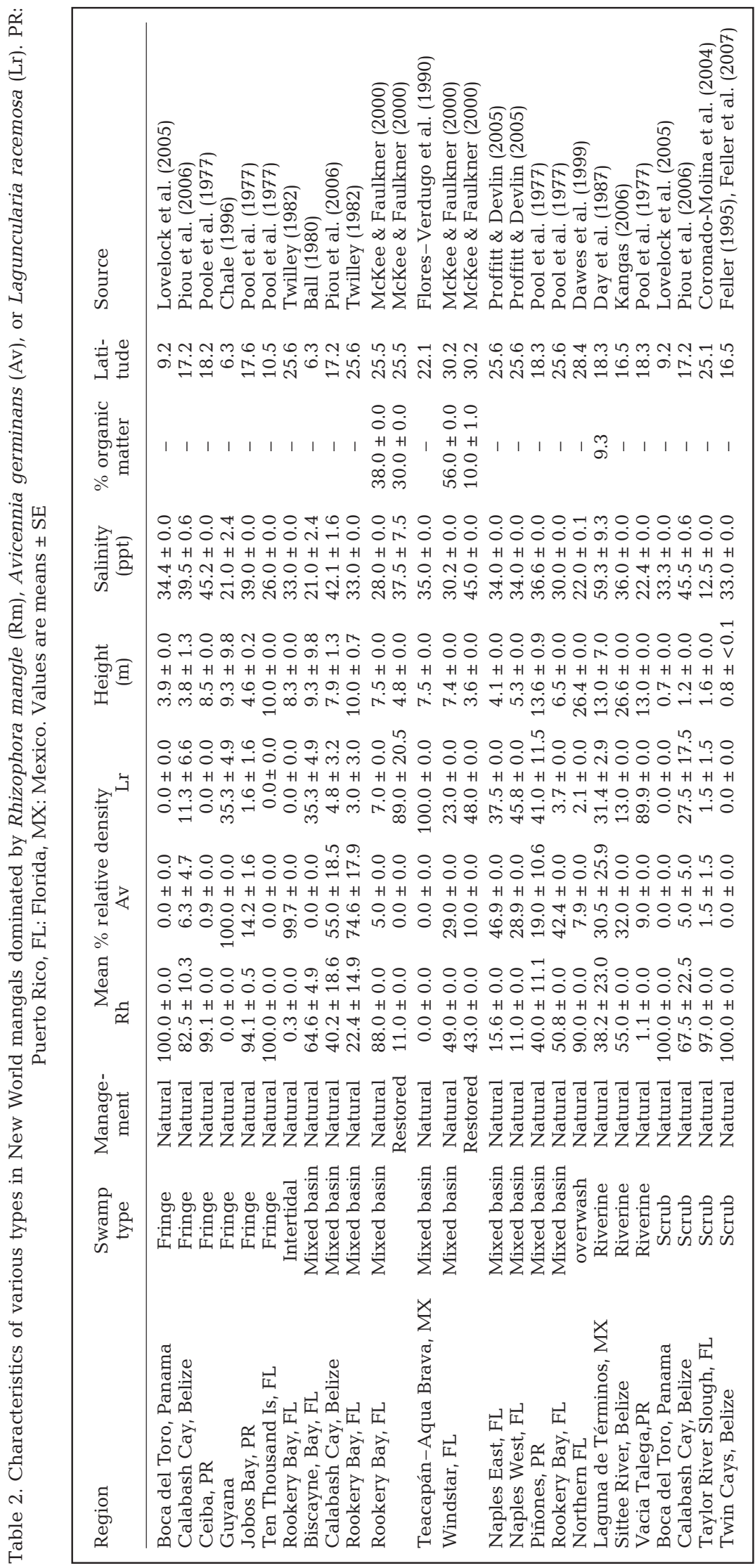




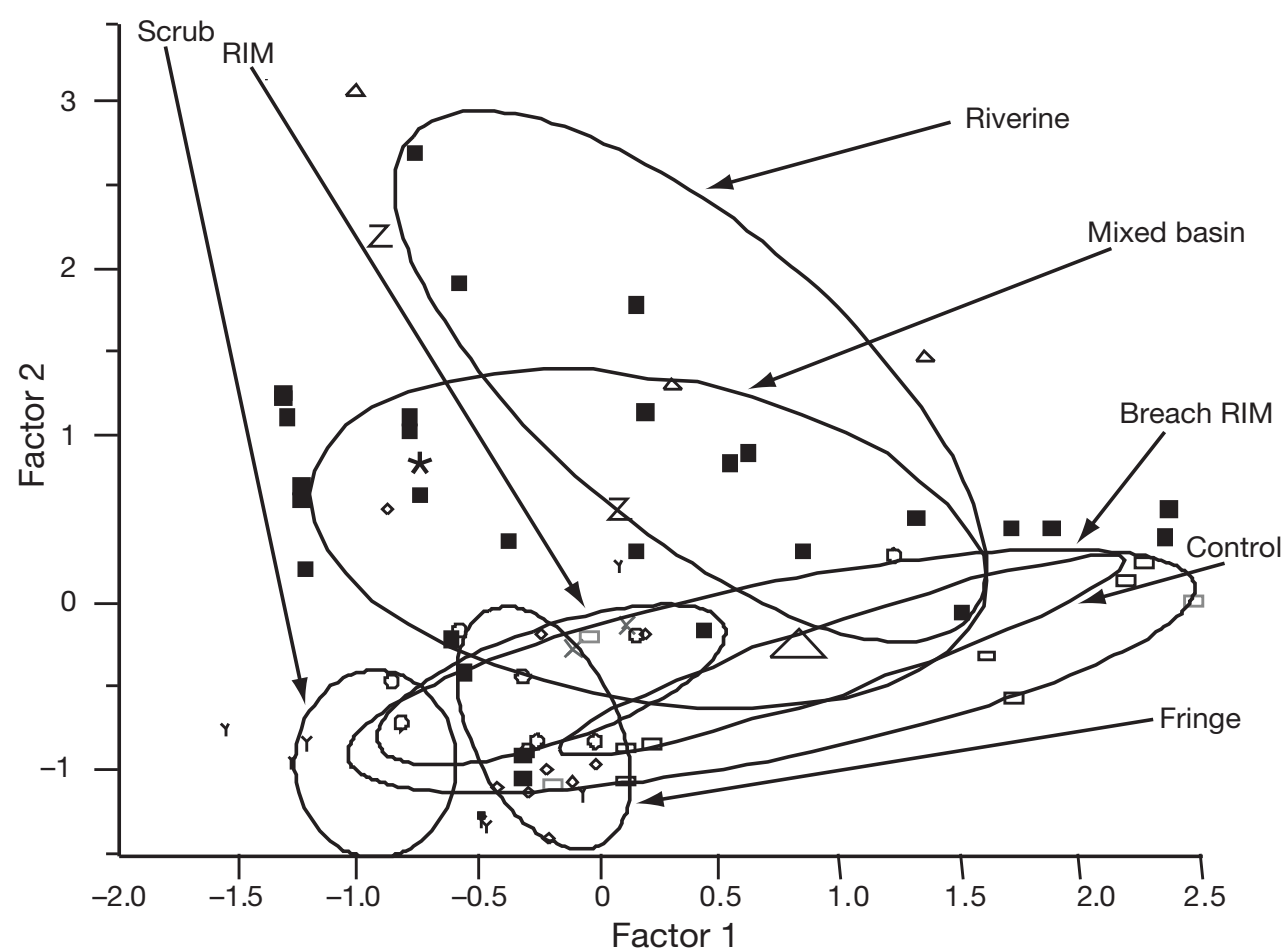

Fig. 3. Principal Component Analysis with Varimax factor rotation of the characteristics of various mangrove types. Two axes were interpreted, with Factor 1 and Factor 2 related to $40.1 \%$ and $27.4 \%$ of the variability, respectively. Factor 1 was related to salinity and the relative densities of Avicennia germinans (69.6 and $91.0 \%$ variability, respectively). Factor 2 was related to maximum tree height $(\mathrm{m})$, and the relative densities of Laguncularia racemosa (56.5 and $82.7 \%$, respectively). Density ellipses set at 0.5 probability were drawn for mangrove types including mixed basin, riverine, fringe, scrub, and mixed basin in this study including RIM (rotational impoundment management), and breached RIM (former RIM site now restored). Symbols represent sites of mangrove types including mixed basin ( $\square$ ), mixed basin this study ( $\square)$, RIM (O), restored RIM this study ( $\square)$, fringe $(\diamond)$, riverine $(\Delta)$, overwash $(*)$, scrub $(Y)$, and restored basin not this study $(\mathrm{Z})$. See Table 2 for sources and means of data

types, so that RIM swamps were positioned on the lower end of PCA Factor 1 (40.1\% of variability). BreachedRIM and control swamps of our study had a wider range of occurrence across Factor 1 (Fig. 3), and thus had the greatest overlap with mixed basin swamps. All swamp types in the present study (RIM, breached-RIM and control swamps) had narrow ranges of values for Factor 2, which represented tree height and the relative density of Laguncularia racemosa (27.4\% of variability). Other New World types, including riverine, mixed basin, and fringe swamps, had more widely variable values for Factor 2 than the swamps in this study.

RIM swamps were most similar to the control and breached-RIM swamp types, even though RIM swamps were less variable than the other 2 types with respect to salinity, tree height and species composition based on density (Fig. 3). Nevertheless, RIM swamps differed from control and breached-RIM swamps because in the PCA analysis using the more extensive variables measured in this study (e.g. soil organic matter, canopy openness), RIM swamps had little overlap with control and breached-RIM swamps with respect to Factors 1 and 2 (Fig. 4).

\section{Structural complexity}

Rhizophora mangle had a higher relative mean density in RIM than in breached and control swamps (78.1, 56.0, and 46.2\%, respectively; $t=1398.7, \mathrm{p}<0.0001$ ). Avicennia germinans had a higher relative mean density in control swamps than in both breached-RIM and RIM swamps (44.3, 34.0, and $11.9 \%$, respectively; $t=1381.2$, $\mathrm{p}<0.0001$ ). Laguncularia racemosa had a higher relative density in breached-RIM swamps than in RIM and control swamps (17.4, 9.2, and $1.9 \%$, respectively; $t=1421.0$, $\mathrm{p}<0.0001)$. Mean relative tree densities were highest in RIM swamp, and lower in both control and breachedRIM swamps (157.8, 133.7 and 124.0 trees per $100 \mathrm{~m}$ transect, respectively; $t=1360.5, \mathrm{p}<0.0005$ ).

Mean tree heights $(\mathrm{m})$ were taller in control than in breached-RIM and RIM swamps (Table 3). BreachedRIM swamps had more variation in tree height than control and RIM swamps (variance $=2.41 \pm 1.30 \mathrm{~m}$ vs. $0.16 \pm$ $0.09 \mathrm{~m}$, respectively; $t=3.42, \mathrm{p}=0.0035)$. Trees attained maximum height within 40 to $75 \mathrm{yr}$ (Fig. 5). Tree height was not related to pore water salinity $(\mathrm{r}=0.05, \mathrm{p}=$ $0.9651)$. 


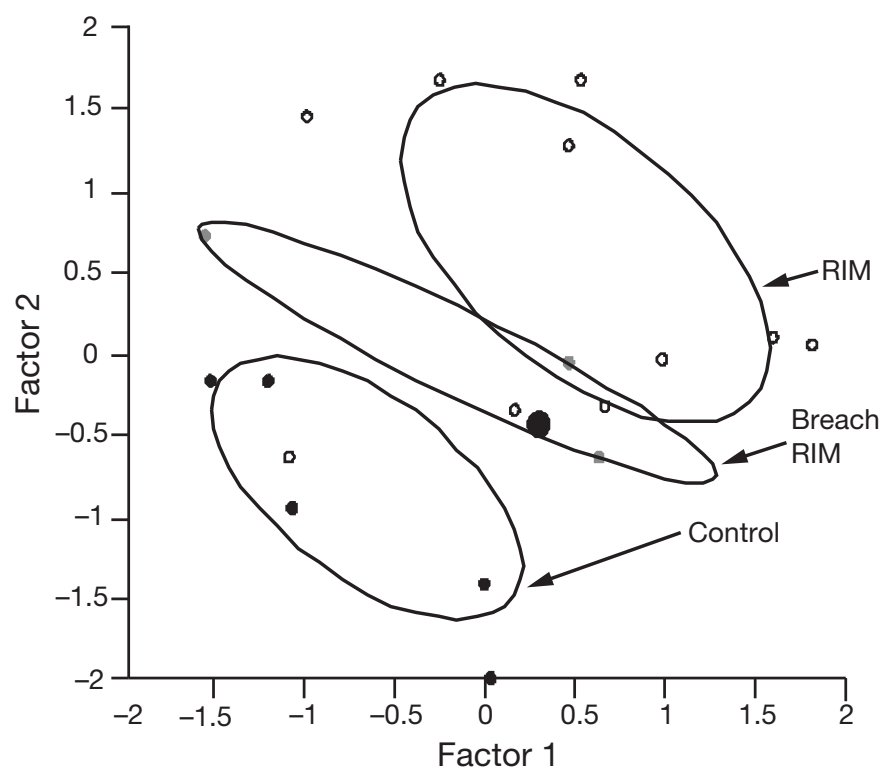

Fig. 4. Principal Component Analysis with Varimax factor rotation of the characteristics of mangroves managed for mosquito control (control, RIM [rotational impoundment management], breached-RIM [former RIM site now restored]) in western Florida. Two axes were interpreted, with Factor 1 and Factor 2 related to 37.4 and $19.4 \%$ of the variability, respectively. Factor 1 was related to relative density of Rhizophora mangle, percent organic matter, leaf area index (LAI), and relative density of Schinus terebinthifolius. Factor 2 was related to the relative densities of Laguncularia racemosa and Avicennia germinans. Density ellipses set at 0.5 probability were drawn for management types including control, breached-RIM, and RIM

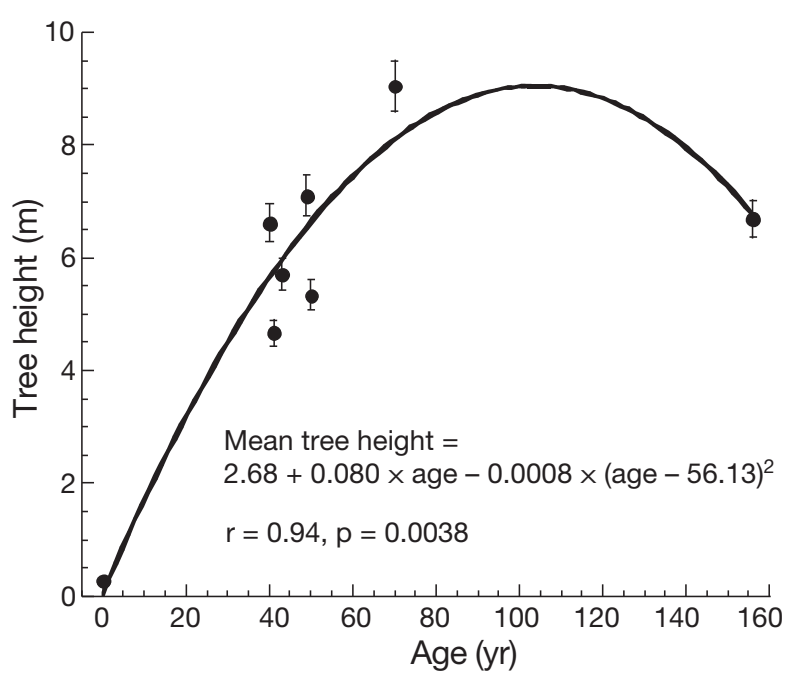

Fig. 5. Second order polynomial regression of age of swamp versus tree height $(\mathrm{m})($ mean $\pm \mathrm{SE}, \mathrm{r}=0.94, \mathrm{p}=0.0038)$. Age of the swamp is based on the time that trees began to grow on the swamp, e.g. time since last killing frost, island formation, or start of RIM management
Canopy openness was higher in control and breached-RIM swamps than in RIM swamps $(\mathrm{p}<$ 0.0001; Table 3). The mean values for LAI control, breached-RIM and RIM swamps were $3.84 \pm 0.11$, $3.47 \pm 0.32$ and $4.09 \pm 0.18$, respectively. Not surprisingly, the statistical comparisons of the LAI means did not differ from those of canopy openness. The variance in canopy openness did not differ among the three management types $\left(F_{2,17}=0.341, \mathrm{p}=0.716\right)$. Canopy openness decreased with the age of the swamp (Fig. 6).

The number of propagules on the ground was higher in breached-RIM and RIM swamps than in control swamps (Table 3). The number of propagules did not vary for Avicennia germinans, Laguncularia racemosa, or Rhizophora mangle among the management types (Chi-square < 0.1, p = 1.0).

Species richnesses of tree and herbaceous species were similar among management types (mean $=2.0$ to 2.4 tree species per transect, and 0 to 1 herbaceous species per site; $\mathrm{p}>0.8187$ ).

\section{Resistance to invasion}

The invasive Schinus terebinthifolius (Brazilian pepper, Anacardiaceae) had a higher relative density in RIM swamps than in control and breached-RIM swamps $(\%$ relative density $=1.0$ vs. 0.0 , respectively; $\mathrm{p}<0.0001)$. S. terebinthifolius was sampled only in RIM swamps with pore water salinities $<2.5$. Pore water salinity was lower in breached-RIM and RIM swamps than in control swamps ( $p<0.0001$; Table 3).

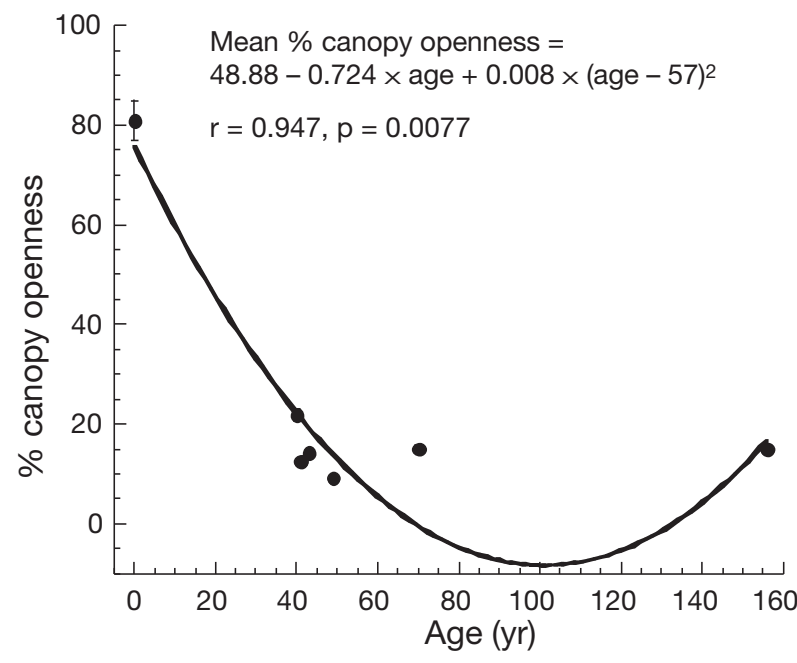

Fig. 6. Second order polynomial regression of age of swamp versus canopy openness $(\%)($ mean $\pm S E, r=0.947, p=0.0077$ ) 
Table 3. Means $( \pm$ SE) for response variables and general linear model (GLM) comparisons for different impoundment management types including natural (unmanaged control), restored (Breach; seasonal flooding, formerly impounded with dike removed, breached or culverts opened), and RIM (rotational impoundment management) in St. Lucie and Indian River Counties, Florida. Chi-square tests are based on GLM comparisons. p values are unadjusted. Based on multiple comparisons using contrasts, means that are significantly different from one another $(\mathrm{p}<0.05)$ are designated by superscripted uppercase letters $(A, B, C)$. Based on Bonferroni corrections, adjusted significances were determined for 3 one degree of freedom contrasts as $p=0.0167$, and for 4 one degree of freedom contrasts as $\mathrm{p}<0.0125$, with significant contrasts designated '*'

\begin{tabular}{|c|c|c|c|c|c|c|c|c|}
\hline \multirow{2}{*}{$\begin{array}{l}\text { Response } \\
\text { variables }\end{array}$} & \multicolumn{3}{|c|}{ Impoundment management type } & \multirow{2}{*}{$\begin{array}{c}\text { Chi-Square } \\
\text { Model }\end{array}$} & \multirow{2}{*}{$\begin{array}{c}\text { Model } \\
\mathrm{p}\end{array}$} & \multirow[t]{2}{*}{ Contrast } & \multirow[t]{2}{*}{$t$} & \multirow[t]{2}{*}{$\mathrm{p}$} \\
\hline & Control & Breach & RIM & & & & & \\
\hline \multirow{4}{*}{$\begin{array}{l}\text { Tree height } \\
\text { (m) }\end{array}$} & $6.7 \pm 0.2^{\mathrm{A}}$ & $6.5 \pm 1.1^{\mathrm{B}}$ & $6.0 \pm 0.4^{\mathrm{B}}$ & 92.1 & $<0.0001$ & Control vs. Breach & 6.7 & $0.0099^{*}$ \\
\hline & & & & & & Breach vs. RIM & 4.9 & 0.0270 \\
\hline & & & & & & Control vs. RIM & 25.7 & $<0.0001^{*}$ \\
\hline & & & & & & Control vs. Breach/RIM & 18.9 & $<0.0001$ \\
\hline \multirow{4}{*}{$\begin{array}{l}\text { Canopy } \\
\text { openness (\%) }\end{array}$} & $14.8 \pm 0.8^{\mathrm{A}}$ & $16.9 \pm 3.1^{\mathrm{A}}$ & $13.6 \pm 1.2^{\mathrm{B}}$ & 79.5 & $<0.0001$ & Control vs. Breach & 5.8 & 0.0155 \\
\hline & & & & & & Breach vs. RIM & 18.1 & $0.0001^{*}$ \\
\hline & & & & & & Control vs. RIM & 7.7 & $0.0054^{*}$ \\
\hline & & & & & & Control//Breach vs. RIM & 18.3 & $<0.0001^{*}$ \\
\hline \multirow{4}{*}{$\begin{array}{l}\text { Number of } \\
\text { propagules } \mathrm{m}^{-2}\end{array}$} & $3.0 \pm 0.8^{\mathrm{A}}$ & $6.1 \pm 2.3^{\mathrm{B}}$ & $5.7 \pm 1.3^{\mathrm{B}}$ & 127.1 & $<0.0001$ & Control vs. Breach & 13.0 & $0.0003^{*}$ \\
\hline & & & & & & Breach vs. RIM & 1.5 & 0.2175 \\
\hline & & & & & & Control vs. RIM & $<0.1$ & $0.9941^{*}$ \\
\hline & & & & & & Control vs. Breach/RIM & 13.1 & $0.0003^{*}$ \\
\hline \multirow[t]{3}{*}{ Salinity (ppt) } & $4.5 \pm 0.1^{\mathrm{A}}$ & $3.8 \pm 0.2^{\mathrm{B}}$ & $3.4 \pm 0.2^{\mathrm{C}}$ & 81.7 & $<0.0001$ & Control vs. Breach & 20.2 & $<0.0001^{*}$ \\
\hline & & & & & & Breach vs. RIM & 18.1 & $<0.0001^{*}$ \\
\hline & & & & & & Control vs. RIM & 62.8 & $<0.0001^{*}$ \\
\hline \multirow{4}{*}{$\begin{array}{l}\text { Soil organic matter } \\
(\%)\end{array}$} & $16.0 \pm 3.0^{\mathrm{A}}$ & $16.8 \pm 4.4^{\mathrm{A}}$ & $36.6 \pm 4.8^{\mathrm{B}}$ & 74.6 & $<0.0001$ & Control vs. Breach & $<0.1$ & 0.9578 \\
\hline & & & & & & Breach vs. RIM & 26.1 & $<0.0001^{*}$ \\
\hline & & & & & & Control vs. RIM & 33.5 & $<0.0001^{*}$ \\
\hline & & & & & & Control/Breach vs. RIM & 37.7 & $<0.0001^{*}$ \\
\hline \multirow{3}{*}{$\begin{array}{l}\text { Litter cover } \\
(\%)\end{array}$} & $0.7 \pm 0.1^{\mathrm{A}}$ & $75.0 \pm 11.6^{\mathrm{B}}$ & $66.7 \pm 5.0^{\mathrm{C}}$ & 2815.3 & $<0.0001$ & Control vs. Breach & 2787.6 & $<0.0001^{*}$ \\
\hline & & & & & & Breach vs. RIM & 2601.4 & $<0.0001^{*}$ \\
\hline & & & & & & Control vs. RIM & 2795.7 & $<0.0001^{*}$ \\
\hline \multirow{4}{*}{$\begin{array}{l}\text { Crab holes } \\
\mathrm{m}^{-2}\end{array}$} & $25.7 \pm 4.2^{\mathrm{A}}$ & $3.0 \pm 1.6^{\mathrm{B}}$ & $5.3 \pm 2.2^{\mathrm{B}}$ & 712.2 & $<0.0001$ & Control vs. Breach & 43.8 & $<0.0001^{*}$ \\
\hline & & & & & & Breach vs. RIM & $<0.1$ & 0.9993 \\
\hline & & & & & & Control vs. RIM & $<0.1$ & 0.9924 \\
\hline & & & & & & Control vs. Breach/RIM & 58.8 & $<0.0001$ \\
\hline
\end{tabular}

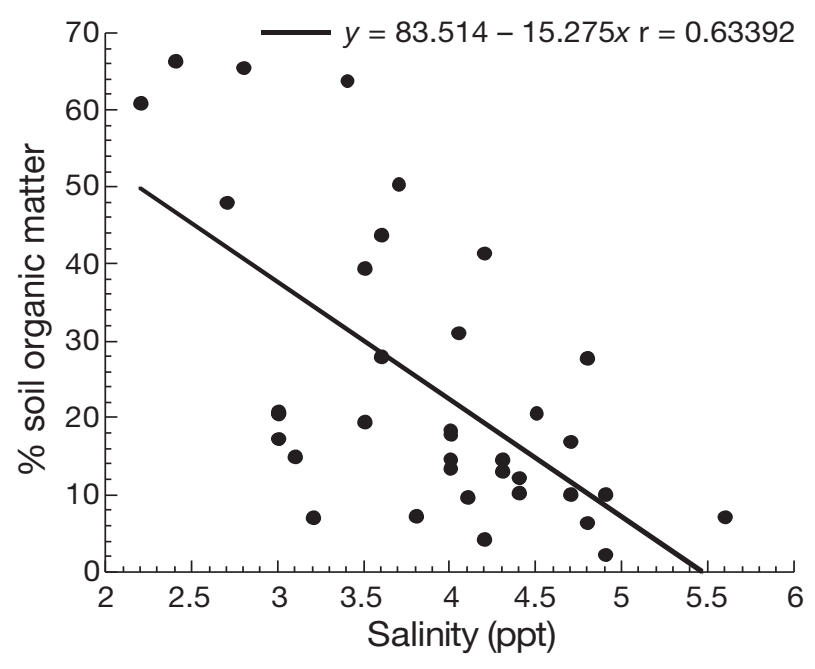

Fig. 7. Linear regression of pore water salinity versus \% soil organic matter in mangrove swamps $(\mathrm{r}=0.634, \mathrm{p}<0.0001)$

\section{Soil development}

The amount of soil organic matter was more than twice as high in RIM swamps than in control and breached-RIM swamps ( $<0.0001$; Table 3). Percent soil organic matter decreased as salinity increased (Fig. 7). Litter cover on the ground was almost 2 orders of magnitude lower in control swamps than in RIM and breached-RIM swamps ( $<<0.0001$; Table 3$)$. The density of crab holes was 5 to 10 times higher in control swamps than in breached-RIM or RIM swamps $(25.7 \pm$ 4.3 vs. $4.6 \pm 1.6$ crab holes $\mathrm{m}^{-2} ; \mathrm{p}<0.0001$; Table 3 ).

\section{DISCUSSION}

\section{RIM mangrove type}

RIM swamps are highly managed, so it is important to determine whether they resemble natural (control) 
swamps in some ways, and if they do, to identify which types of swamps they most closely resemble. To answer this, we compared RIM swamps to other New World mangrove swamp types. RIM, control and breached-RIM were most similar to basin and fringe type swamps, which tend to be dominated by Rhizophora mangle and/or Avicennia germinans (Fig. 2, Table 2). Nevertheless, structural comparisons supported the idea that RIM swamps had underlying differences from the other swamp types in this study. Furthermore, breached-RIM swamps may take some time to recover from RIM management because they differed in many characteristics from natural (control) swamps.

\section{Structural characteristics and ecosystem processes}

Our simple survey of structural characteristics did not reveal any true differences in ecosystem function between the mangrove swamps managed for mosquito control. Nevertheless, the measurements indicated that these swamps are different in several ways. The differences we observed in the structural characteristics of managed mangrove swamps and the measured differences in soil development, support of biota, and resistance to invasion indicate that ecosystem functions such as production, decomposition, nutrient cycling, and trophic dynamics may vary in relation to RIM management (Fig. 8). Our findings do not allow us to predict whether the structural characteristics of managed mangrove ecosystems will become similar to natural (control) swamps over time, which is an important question for breached-RIM swamps.

\section{Forest structural complexity}

Simple comparisons of the structural complexity of managed mangrove systems can give insight into the value of these systems to wildlife. For example, seem- ingly small structural differences in the height of vegetation can affect the value of wetlands as wildlife habitat. In restored coastal marshes in California, California cordgrass Spartina foliosa growing on nutrientpoor dredge spoil may be too short to support nesting of the endangered bird species Rallus longirostris obsoletus (California clapper rail; Zedler 1993, Zedler \& Callaway 1999). Similarly, eagles prefer taller and older trees for nesting (Kralovec et al. 1992, Garrett et al. 1993, Stohlgren 1993). These 2 examples demonstrate that differences in stand heights of other vegetation types can affect wildlife, thus it is possible that height differences in managed mangrove systems might also affect their value as wildlife habitats. In the present study, the mean height of trees in control mangrove swamps was $0.5 \mathrm{~m}$ taller than in RIM and breached-RIM (restored) mangrove swamps. Also, breached-RIM swamps were more structurally complex because their tree height variance was greater than in control and RIM swamps (variance $=2.41$ vs. $0.16 \mathrm{~m}$, respectively). While we cannot provide any examples of how these specific structural differences in tree height may affect wildlife in these mangrove swamps, it is worth noting that these forests are not structurally similar in mangrove tree height.

We calculated the time to attain the full tree height. According to models, $75 \%$ of the basal dominance (and presumably height) of mangrove swamps is attained $40 \mathrm{yr}$ after restoration (Twilley et al. 1997). Trees in the present study attained the greatest height approximately 40 to $75 \mathrm{yr}$ (Fig. 4) after disturbance, e.g. freezing, hurricane, or tree removal before RIM management. Trees in the oldest mangrove forests in this study of eastern Florida were shorter than those in Central and South America (Tables 2 \& 3), perhaps because of shorter growing seasons. While previous studies indicate that mangroves are shorter in environments with increased salinity (Cintrón et al. 1975), we did not detect this relationship between salinity and tree height, perhaps because our sites did not have a large range of salinities.

\begin{tabular}{|c|c|c|}
\hline $\begin{array}{l}\text { Controlling } \\
\text { factors }\end{array}$ & $\begin{array}{l}\text { Structural } \\
\text { complexity }\end{array}$ & $\begin{array}{l}\text { Ecosystem } \\
\text { functions }\end{array}$ \\
\hline $\begin{array}{l}\text { Flooding } \\
\text { Salinity } \\
\text { Aeration by crab holes }\end{array}$ & $\begin{array}{l}\text { Tree height } \\
\text { Canopy openness } \\
\text { Tree density } \\
\text { Regeneration } \\
\text { Ground cover } \\
\text { Litter Cover }\end{array}$ & $\begin{array}{l}\text { Support of biota } \\
\text { Resistance to invasion } \\
\text { Soil development }\end{array}$ \\
\hline
\end{tabular}

Fig. 8. Conceptual model of the relationships among controlling factors, structural characteristics and ecosystem functions in mangrove swamps 
Canopy openness and tree density are structural components that influence the light and temperature environment of the forest floor, and so are important forest structure characteristics contributing to the dynamics of forest patches (Pickett \& White 1985). Canopy structure was an important predictor of benthic primary production because of the relationship of canopy height to photosynthesis and irradiance in macroalgal communities of shallow coastal water (Middelboe et al. 2006). We found differences in canopy openness among the various mangrove management types in our study; canopy openness was lowest in RIM and higher in control and breached-RIM swamps (Table 3). Similarly, trees were denser in RIM than in control and breached-RIM swamps. Tree density typically declines as canopy closes during succession (Proffitt \& Devlin 2005). Nevertheless, the differences in canopy structure of these mosquitomanaged mangrove swamps indicate that the patchy environment on the forest floors may differ among swamp types.

Differences in dominant species composition in mangrove swamps by management type could affect ecosystem processes. Mangrove species and their associated vegetative organs (roots, leaves, twigs) have different inherent breakdown rates (Middleton \& McKee 2001), so that the relative composition and production levels of swamps may affect nutrient cycling and trophic dynamics. For example, mangrove swamps dominated by Avicennia germinans have faster nutrient cycling rates than those dominated by Laguncularia racemosa and Rhizophora mangle (McKee \& Faulkner 2000). In this study, we found differences in dominant species frequency; the highest frequencies for Avicennia germinans were found in control swamps, while highest frequencies of Rhizophora mangle occurred in breached-RIM and RIM swamps. The low ground cover in control swamps may be related to the tidal movement of objects in swamps; breached-RIM and RIM swamps are not often influenced by tides because the levees restrict water movement.

\section{Resistance to invasion}

Lower species richness in saline wetlands may be mainly related to reduced seed germination and seedling recruitment of both native and non-native species under saline conditions, even though these species may be tolerant of higher levels of salinity as adults. For example, Typha domingensis invades California salt marshes when water freshens (Beare \& Zedler 1987). Native species richness is limited across an increasing saltwater gradient, and even the growth of salt tolerant species tends to be higher in coastal wetlands with lower salinity (Crain et al. 2004). Therefore, in the context of mangrove swamps managed for mosquito control, one might infer that RIM swamps with lower salinity water than other swamps may be more subject to invasion by non-native species; however, that was only true for one invasive species, Schinus terebinthifolius.

Schinus terebinthifolius had invaded only RIM swamps with the lowest pore water salinity levels (2 swamps with mean salinity of 2.5) in this study. Similarly, in the Florida Everglades, $S$. terebinthifolius invasion is more successful at reduced salinities that promote better germination and survival of seedlings (salinity <5; Mytinger \& Williamson 1987). The results of both of these studies suggest that the invasion of $S$. terebinthifolius might be facilitated in RIM swamps by the lower salinity. Apart from the invasion of $S$. terebinthifolius in RIM swamps, there were no other indications of differences in species richness of native trees or herbaceous species among RIM, breached-RIM or control swamps (Table 3).

\section{Soil development}

Organic matter accumulation in soils has complex relationships with production, decomposition and nutrient cycling, as well as soil factors such as soil permeability, moisture retention, and cation exchange capacity. Because of its importance as an indicator of biogeochemical processing, the status of soil organic matter accumulation has become an important consideration in assessing the success of wetland restoration projects (Craft et al. 1988, 1999). It is generally assumed that organic matter levels will increase with time of recovery in restored wetlands (Craft et al. 1988, 1999) and that, initially, organic matter levels are lower in restored or created wetlands than in natural (control) wetlands (Bischel-Machung et al. 1996, Shaffer \& Ernst 1999). In the present study, we found that this simple relationship does not adequately describe soil organic matter content in control versus managed swamps; RIM swamps had more than twice as much soil organic matter than both control and restored (breached-RIM) mangals (Table 3). Therefore, the interesting question here is: why are organic matter levels higher in highly managed RIM swamps than in control and restored swamps?

Perhaps the best explanation is that RIM swamps are flooded during the summer (Fig. 2) and anoxic conditions slow the rate of decomposition (Brinson et al. 1981, McKee \& Faulkner 2000). During this same time period, water levels in control and breached-RIM mangrove swamps are drawn down, resulting in lower 
amounts of organic matter accumulation. In addition, RIM swamps are not subjected to tidal flushing. Thus, the differences in summer hydrology between RIM versus breached-RIM and control swamps could explain the relatively high accumulation of organic matter in RIM swamps. The nature and timing of water delivery in wetlands is recognized as a critical factor in restoration (Middleton 1999).

Another Florida study compared the soil organic matter of restored versus control sites (10 to $12 \%$ vs. 38 to $56 \%$ soil organic matter; McKee \& Faulkner 2000), but did not include observations of RIM swamps. The soil organic matter levels of restored sites in our study were higher than in those studied by McKee \& Faulkner (2000). Swamps we studied were restored over former RIM swamps (with high levels of organic matter), while the swamps examined by McKee \& Faulkner (2000) were restored over dredge spoil. Another difference between our findings and those of McKee \& Faulkner (2000) was that control swamps in our study had low amounts of organic matter (mean = $16.8 \%)$. While the control swamps in the McKee \& Faulkner study (2000) were somewhat sheltered from the open ocean, the control swamps we examined were adjacent to the open ocean, with potential for input of mineral particles or export of organic matter during storms. The differences in the organic matter levels in these 2 studies are largely attributable to site position and substratum origin.

\section{Support of burrowing crabs}

The burrows of crabs such as the fiddler crab $U_{C a}$ pugnax play an important role in stimulating the production, decomposition and nutrient cycling of coastal wetlands because crab burrows increase the level of drainage, aeration, redox, and decomposition in the soil (Bertness 1985, Robertson 1986, Robertson \& Daniel 1989, Colpo \& Negreiros-Fransozo 2004). The nature of the reestablishment of crabs and their activities may be vital to the overall success of the restoration of biogeochemical processes.

In our study, breached-RIM (restored) and RIM swamps had densities of crab holes that were $80 \%$ lower than those of control swamps (4.6 vs. $25.7 \mathrm{crab}$ holes $\mathrm{m}^{-2}$, respectively; Table 3 ). These results are similar to those found in damaged versus control swamps in North Queensland, Australia (0 to 60 vs. 117 crab holes $\mathrm{m}^{-2}$, respectively; Kaly et al. 1997). The reason for low crab population numbers in RIM swamps may be related to hydrological differences in the summer, as described previously. RIM swamps are flooded during the summer while control swamps are drawn down during this period (Fig. 2). UCa pugnax is an intertidal species that requires oxygen (Teal 1959); consequently, this species may avoid RIM swamps with longer periods of annual flooding (Fig. 1). BreachedRIM (restored) swamps also have low numbers of crabs; these swamps may be too dry for crabs, or crab densities may increase slowly after RIM management ceases. Hydrological dissimilarities among RIM, breached-RIM and control mangrove swamps are likely the underlying cause for the different levels of crab activity in these swamps. For mangrove swamp restoration to be more successful, attention should be given to creating hydrological and other environmental conditions that are conducive to crab colonization and success.

\section{CONCLUSIONS}

Our simple characterizations of structural complexity, resistance to invasion, soil development and support of biota revealed differences among RIM, breached-RIM, and control mangrove swamps. These differences may mirror shifts in ecosystem processes related to production, decomposition, nutrient cycling, and trophic dynamics, as related to the contrasting hydrology of control versus managed swamps. RIM swamps are impounded by levees, so that these swamps have a relatively limited amount of direct tidal flow. In addition, water is pumped into the impoundment during summer, a time when control mangrove swamps tend to be drawn down. In addition, breached-RIM sites are subject to altered hydrology because of remaining levee structures. These swamps, which are managed in various ways for mosquito control along the coast of eastern Florida, differed in species composition, stand height, canopy openness and tree density, resistance to invasion, soil development, and crab activity compared to control marshes. The present study provides a simple characterization of observed differences among these swamps that likely reflect underlying differences in ecosystem processes.

Acknowledgements. Funding for this project was provided by US Fish and Wildlife Service project no. 401816N003, Comparison of vegetation and soil development in mangrove restoration areas following various restoration procedures. We thank J. David and M. Toliver of the St. Lucie Mosquito Control Management District, and D. Carlson, J. Beidler, and B. Reeves of the Indian River Mosquito Control Management District for their field and logistical assistance and natural history information. Also thanks to the St. Lucie Mosquito Control Management District via L. Goldsmith for the water data used in the hydrographs. E. Travis provided laboratory support. R. Dale gave statistical advice. E. Ramsey and R. Howard gave helpful comments on earlier drafts of the manuscript. 


\section{LITERATURE CITED}

Ball MC (1980) Patterns of secondary succession in a mangrove forest of southern Florida. Oecologia 44:226-235

Beare PA, Zedler JB (1987) Cattail invasion and persistence in a coastal salt marsh: the role of salinity reduction. Estuaries 10:165-170

Bertness MD (1985) Fiddler crab regulation of Spartina alterniflora production on a New England salt marsh. Ecology 66:1042-1055

Bischel-Machung L, Brooks RP, Yates SS, Hoover KL (1996) Soil properties of reference wetlands and wetland creation projects in Pennsylvania. Wetlands 16:532-541

Brinson MM, Rheinhardt R (1996) The role of reference wetlands in functional assessment and mitigation. Ecol Appl 6:69-76

Brinson MM, Lugo AE, Brown S (1981) Primary productivity, decomposition, and consumer activity in freshwater wetlands. Annu Rev Ecol Syst 12:123-161

Brower JE, Zar JH, von Ende CN (1997) Field and laboratory methods for general ecology. WCB McGraw-Hill, Boston, MA

> Chale FMM (1996) Litter production in an Avicennia germinans (L.) Stearn forest in Guyana, South America. Hydrobiologia 330:47-53

Cintrón G, Lugo AE, Pool DJ, Morris G (1975) Mangroves of arid environments in Puerto Rico and adjacent islands. Biotropica 10:110-121

Collins JN, Resh VH (1989) Guidelines for the ecological control of mosquitoes in non-tidal wetlands of the San Francisco Bay area. California mosquito vector control association Inc and University of California Mosquito Research Program, Sacramento, CA

Colpo KD, Negreiros-Fransozo ML (2004) Comparison of the population structure of the fiddler crab Uca vocator (Herbst, 1804) from three subtropical mangrove forests. Sci Mar 68:139-146

Coronado-Molina C, Day JW Jr, Reyes E, Perez BC (2004) Standing crop and aboveground biomass partitioning of a dwarf mangrove forest in Taylor River Slough, Florida. Wetlands Ecol Manag 12:157-164

Craft CB, Broome SW, Seneca ED (1988) Nitrogen, phosphorus and organic carbon pools in natural and transplanted marsh soils. Estuaries 11:272-280

Craft CB, Reader J, Sacco JN, Broome SW (1999) Twentyfive years of ecosystem development of constructed Spartina alterniflora (Loisel) marshes. Ecol Appl 9: 1405-1419

Crain CM, Silliman BR, Bertness SL, Bertness MD (2004) Physical and biotic drivers of plant distribution across estuarine salinity gradients. Ecology 85:2539-2549

Dawes C, Siar K, Marlett D (1999) Mangrove structure, litter and macroalgal productivity in a northern-most forest of Florida. Mangroves Salt Marshes 3:259-267

- Day JW Jr, Conner WH, Ley-Lou F, Day RH, Machado Navarro A (1987) The productivity and composition of mangrove forests, Laguna de Términos, Mexico. Aquat Bot 27:267-284

Ellison AM (2000) Mangrove restoration: do we know enough? Restor Ecol 8:219-229

Feller IC (1995) Effects of nutrient enrichment on growth and herbivory of dwarf red mangrove (Rhizophora mangle). Ecol Monogr 65:477-505

Feller IC, Lovelock CE, McKee KL (2007) Nutrient addition differentially affects ecological processes of Avicennia germinans in nitrogen versus phosphorus limited mangrove ecosystems. Ecosystems 10:347-359
Field CC (1999) Rehabilitation of mangrove ecosystems: an overview. Mar Pollut Bull 37:8-12

Flores-Verdugo F, Gonzáles-Farías R, Ramírez-Flores O, Amezcua-Linares F, Yáñez-Arancibia A, Alvarez-Rubio M, Day JW Jr (1990) Mangrove ecology, aquatic primary productivity, and fish community dynamics in the Teacapán-Aqua Brava Lagoon-Estuarine System (Mexican Pacific). Estuaries 13:219-230

Frazer G, Trofymow J, Lertzman K (1997) A method for estimating canopy openness, effective leaf area index, and photosynthetically active photon flux density using hemispherical photography and computerized image analysis techniques. Report BC-X-373. Natural Resources Canada, Canadian Forest Service, Pacific Forestry Centre Information, Victoria, BC

Frazer G, Canham C, Lertzman K (1999) Gap Light Analyzer (GLA), Version 2.0: Imaging software to extract canopy structure and gap light transmission indices from truecolor fisheye photographs, user manual and program documentation. Simon Fraser University, Burnaby, BC and the Institute of Ecosystem Studies, Millbrook, NY

- Garrett MG, Watson JW, Anthony RB (1993) Bald eagle home range and habitat use in the Columbia River estuary. J Wildl Manag 57:19-27

Heiri O, Lotter AF, Lemcke G (2001) Loss on ignition as a method for estimating organic and carbonate content in sediments: reproducibility and comparability of results. J Paleolimnol 25:101-110

JMP SAS (2007). JMP Statistical Analysis System, Version 7.0.1. Cary, NC

Kadlec R, Knight R, Vymazal J, Brix H, Cooper P, Haberl R (2000) Constructed wetlands for pollution control. Scientific and technical report No. 8, IWA Specialist group on use of macrophytes in water pollution control, International Water Association, London

> Kaly UL, Eugelink G, Robertson AI (1997) Soil condition in damaged North Queensland mangroves. Estuaries 20:291-300

Kangas P (2006) Mangrove forest structure on the Sittee River, Belize. Unpublished manuscript, Natural resources management program, University of Maryland, College Park, MD

> Knight RL, Walton WE, O'Meara GG, Reisen WK, Wass R (2003) Strategies for effective mosquito control in constructed treatment wetlands. Ecol Eng 21:211-232

Kralovec ML, Knight RL, Craig GR, McLean RG (1992) Nesting productivity, food habits, and nest sites of bald eagles in Colorado and southeastern Wyoming. Southwest Nat 37:356-361

Lovelock CE, Feller IC, McKee KL, Thompson R (2005) Variation in mangrove forest structure and sediment characteristics in Bocas del Toro, Panama. Caribb J Sci 41:456-464

McKee KL, Faulkner PL (2000) Restoration of biogeochemical function in mangrove forests. Restor Ecol 8:247-259

Middelboe AL, Sand-Jensen K, Binzer T (2006) Highly predictable photosynthetic production in natural macroalgal communities from incoming and absorbed light. Oecologia 150:464-476

Middleton BA (1999) Wetland restoration, flood pulsing and disturbance dynamics. John Wiley \& Sons, New York, NY

Middleton BA, McKee KL (2001) Degradation of mangrove tissues and implications for peat formation in Belizean island forests. J Ecol 89:818-828

Montague CL, Zale AV, Percival HF (1987) Ecological effects of coastal marsh impoundments: a review. Environ Manag $11: 743-756$

Mytinger L, Williamson GB (1987) The invasion of Schinus into saline communities of Everglades National Park. Fla Sci 50:7-12 
Patterson G (2004) The mosquito wars: a history of mosquito control in Florida. University Press of Florida, Gainesville, FL

Pickett STA, White PS (eds) (1985) The ecology of natural disturbance and patch dynamics. Academic Press, San Diego, CA

Piou C, Feller IC, Berger U, Chi F (2006) Zonation patterns of Belizean offshore mangrove forests 41 years after a catastrophic hurricane. Biotropica 38:365-374

Pool DJ, Snedaker SC, Lugo AE (1977) Structure of mangrove forests in Florida, Puerto Rico, Mexico, and Costa Rica. Biotropica 9:195-212

Proffitt CE, Devlin DJ (2005) Long-term growth and succession in restored and natural mangrove forests in southwestern Florida. Wetlands Ecol Manag 13:531-551

Ramsey E III, Jensen J (1995) Modeling mangrove canopy reflectance using a light interaction model and an optimization technique. In: Lyon J, McCarthy J (eds) Wetland and environmental applications of GIS. CRC Press, Boca Raton, FL, p 61-81

Ramsey E III, Jensen J (1996) Remote sensing of mangroves: relating canopy spectra to site-specific data. Photogramm Eng Remote Sensing 62:939-948

Rey JR, Kain T (1990) A guide to the salt marsh impoundments of Florida. Florida Medical Entomology Laboratory Publication, Vero Beach, FL

Robertson AI (1986) Leaf-burying crabs: their influence on energy flow and export from mixed mangrove forests (Rhizophora spp.) in northeastern Australia. J Exp Mar Biol Ecol 102:237-248

Robertson AI, Daniel PA (1989) The influence of crabs on litter processing in high intertidal mangrove forests in tropical Australia. Oecologia 78:191-198

Editorial responsibility: Hans Heinrich Janssen, Oldendorf/Luhe, Germany
Shaffer PW, Ernst TL (1999) Distribution of soil organic matter in freshwater emergent/open water wetlands in the Portland, Oregon metropolitan area. Wetlands 19: $505-516$

Sime P (2005) St. Lucie Estuary and Indian River Lagoon conceptual ecological model. Wetlands 25:898-907

Simenstad CA, Thom RM (1996) Functional equivalency trajectories of the restored Gog-Le-Hi-Te Estuarine Wetland. Ecol Appl 6:38-56

Sokal RR, Rohlf FJ (1995) Biometry. WH Freeman, New York Stohlgren TJ (1993) Bald eagle winter roost characteristics in Lava Beds National Monument, California. Northwest Sci $67: 44-54$

Teal JM (1959) Respiration of crabs in Georgia saltmarshes and its relationship to their ecology. Physiol Zool 32:1-14

Twilley RR (1982) Litter dynamics and organic carbon exchange in black mangrove (Avicennia germinans) basin forest in a southwest Florida estuary. PhD dissertation, University of Florida, Gainesville, FL

> Twilley RR, Pozo M, Garcia VH, Rivera-Monroy VH, Zambrano R, Bodero A (1997) Litter dynamics in riverine mangrove forests in the Guayas River estuary, Ecuador. Oecologia 111:109-122

World Health Organization (1982) Manual on environmental management for mosquito control. WHO Offset Publication \#66, World Health Organization, Geneva, available at: whqlibdoc.who.int/publications/1982/9241700661_eng.pdf

Zedler JB (1993) Canopy architecture of natural and planted cordgrass marshes selecting habitat evaluation criteria. Ecol Appl 3:123-138

Zedler JB, Callaway JC (1999) Tracking wetland restoration: do mitigation sites follow desired trajectories? Restor Ecol $7: 69-73$

Submitted: November 15, 2007; Accepted: August 6, 2008 Proofs received from author(s): November 6, 2008 